Article

\title{
Synthesis and Antiproliferative Activities of Conjugates of Paclitaxel and Camptothecin with a Cyclic Cell-Penetrating Peptide
}

\author{
Naglaa Salem El-Sayed ${ }^{1,2}$, Amir Nasrolahi Shirazi ${ }^{1,3}$, Muhammad Imran Sajid ${ }^{1,4}$, \\ Shang Eun Park ${ }^{1}$, Keykavous Parang ${ }^{1, * \mathbb{D}}$ and Rakesh Kumar Tiwari ${ }^{1, * \mathbb{D}}$ \\ 1 Center for Targeted Drug Delivery, Department of Biomedical and Pharmaceutical Sciences, Chapman \\ University School of Pharmacy, Harry and Diane Rinker Health Science Campus, Irvine, CA 92618, USA; \\ nibrahim@chapman.edu (N.S.E.-S.); ashirazi@ketchum.edu (A.N.S.); sajid@chapman.edu (M.I.S.); \\ park327@mail.chapman.edu (S.E.P.) \\ 2 Cellulose and Paper Department, National Research Center, Dokki 12622, Cairo, Egypt \\ 3 Department of Pharmaceutical Sciences, College of Pharmacy, Marshall B. Ketchum University, \\ Fullerton, CA 92831, USA \\ 4 Faculty of Pharmacy, University of Central Punjab, Lahore 54000, Pakistan \\ * Correspondence: parang@chapman.edu (K.P.); tiwari@chapman.edu (R.K.T.); \\ Tel.: +1-714-516-+5489 (K.P.); +1-714-516-5483 (R.K.T.)
}

Academic Editor: Paula A. C. Gomes

Received: 13 February 2019; Accepted: 6 April 2019; Published: 11 April 2019

\begin{abstract}
Cell-penetrating peptide $[\mathrm{WR}]_{5}$ has been previously shown to be an efficient molecular transporter for various hydrophilic and hydrophobic molecules. The peptide was synthesized using Fmoc/tBu solid-phase chemistry, and one arginine was replaced with one lysine to enable the conjugation with the anticancer drugs. Paclitaxel (PTX) was functionalized with an esterification reaction at the $\mathrm{C}^{\prime}$ hydroxyl group of PTX with glutaric anhydride and conjugated with the cyclic peptide $\left[\mathrm{W}(\mathrm{WR})_{4} \mathrm{~K}(\beta \mathrm{Ala})\right]$ in DMF to obtain the peptide-drug conjugate PTX1. Furthermore, camptothecin (CPT) was modified at the $\mathrm{C}(20)$-hydroxyl group through the reaction with triphosgene. Then, it was conjugated with two functionalized cyclic peptides through a formyl linker affording two different conjugates, namely CPT1 and CPT2. All the conjugates showed better water solubility as compared to the parent drug. The cytotoxicity assay of the drugs and their conjugates with the peptides were evaluated in the human breast cancer MCF-7 cell line. PTX inhibited cell proliferation by $39 \%$ while the PTX-peptide conjugate inhibited the proliferation by $\sim 18 \%$ after $72 \mathrm{~h}$ incubation. On the other hand, CPT, CPT1, and CPT2 reduced the cell proliferation by $68 \%, 39 \%$, and $62 \%$, respectively, in the MCF-7 cell lines at $5 \mu \mathrm{M}$ concentration after $72 \mathrm{~h}$ incubation.
\end{abstract}

Keywords: cell-penetrating peptide; conjugate; camptothecin; cytotoxicity; MCF-7; paclitaxel; solubility

\section{Introduction}

Intensive efforts have been exerted for the development of an intracellular stimuli-responsive drug delivery system that is stable under normal physiological conditions (e.g., in blood circulation) but able to release its payload in the tumor site in a selective and efficient manner [1]. The tumorigenic process and microenvironmental characteristics of the tumor tissue have been extensively studied and used to design and synthesize new targeted molecular therapies [2,3]. More precisely, understanding the tumor microenvironment allows researchers to develop different therapeutic strategies, based on the numerous differences between the tumor microenvironment and the normal tissues [4-6]. 
Cell-penetrating peptides (CPPs) are positively-charged short peptides with 5-30 amino acids that are able to penetrate cell membranes and translocate different types of cargos into cells via different mechanisms such as endocytosis [7]. Interestingly, some CPPs have shown attractive therapeutic and biomedical potential due to their biocompatibility and high level of tissue selectivity through binding to specific cell receptors [8-12]. However, due to their peptide-based nature, they have poor in vitro and in vivo stability, which may demote their bioactivity [13]. Synthetic amphipathic CPPs can tolerate the instability of natural CPPs while retaining their ability to permeate the cells and deliver cargos. Furthermore, the physicochemical profile, self-assembly, receptor recognition, and stimuli-responsive properties of amphipathic CPPs can be engineered by selecting the proper amino acid sequences and peptide secondary structures, which are stabilized by hydrophobic-hydrophilic side chain interactions [14]. Rational functionalization of side chains with acid labile, redox sensitive bonds (ester bond and disulfide bridge), and tumor homing peptide motif, e.g., IKVAV, PEG, KGGVG, and RGD, confer remarkable properties to CPPs, such as peptide stability, control over the rate, and site of cargo release [15-17].

Several studies have revealed the impact of using CPPs as a molecular transporter for many therapeutic agents, which could bind either through physical loading or via chemical conjugation and could be released by microenvironmental stimuli, such as the $\mathrm{pH}$, redox, irradiation, or enzyme [18-23].

Mandal et al. [24] reported the synthesis of a series of linear and cyclic CPPs with alternating tryptophan $(\mathrm{W})$ and arginine $(\mathrm{R})$ amino acids. Mandal et al. study revealed that cyclic peptides $[\mathrm{WR}]_{4}$ and $[\mathrm{WR}]_{5}$ were efficient in translocating the fluorescently-labeled anti-HIV drug (3TC). Furthermore, $[\mathrm{WR}]_{4}$ enhanced the cellular uptake for a number of cell-impermeable phosphopeptides, including the fluorescent-labeled $F^{\prime}$-GpYLPQTV, F'-NEpYTARQ, F'-AEEEIYGEFEAKKKK, F'-PEpYLGLD, $\mathrm{F}^{\prime}$-pYVNVQN-NH${ }_{2}$, and $\mathrm{F}^{\prime}$-GPYEEI in human leukemia cells (CCRF-CEM) [25]. Furthermore, Shirazi et al. employed the cyclic peptide $\left[\mathrm{W}(\mathrm{WR})_{4} \mathrm{~K}\right]$ as a molecular transporter for the delivery of doxorubicin (Dox) and curcumin (Cur) to different cancer cell lines by their loading in a physical mixture or via conjugation to the peptide through a hydrolyzable ester bond with glutamate $[21,26]$. Dox- $\left[\mathrm{W}(\mathrm{WR})_{4} \mathrm{~K}\right]$ conjugate inhibited the cell proliferation of human leukemia (CCRF-CEM), colorectal carcinoma (HCT-116), ovarian adenocarcinoma (SK-OV-3), and breast carcinoma (MDA-MB-468) cells in a range of $50 \%$ to $79 \%$. Flow cytometry evaluation exhibited a 3.6-fold higher uptake of the conjugate versus Dox alone in SK-OV-3 cells. Intracellular hydrolysis of Dox from the conjugate was shown within $72 \mathrm{~h}$ incubation. Meanwhile, cellular uptake of Cur by the CCRF-CEM cancer cell line was improved by 5.7- and 4-fold for the physical mixture and the chemical conjugate, respectively, as compared to Cur alone. In the meantime, the antiproliferative activity of Cur in the physical mixture and the chemical conjugate was enhanced by almost $20 \%$ and $13 \%$, respectively [21].

Paclitaxel (PTX) is a natural compound isolated from the Pacific Yew tree by Wall and Wani in 1967 [27]. PTX interacts with $\beta$-tubulin located inside of the microtubules that induce the microtubules' polymerization, causing the arrest of the cell cycle at the G2/M phase and inducing apoptosis in cancer cells [28]. Camptothecin (CPT) is a natural product isolated from Camptotheca acuminate with anticancer potency. CPT works by inhibiting type I DNA topoisomerase and inducing apoptosis in tumor cells [29]. PTX and CPT have shown broad-spectrum cytotoxic potentiality against ovarian, breast, non-small-cell lung, pancreatic, and brain cancers and Kaposi's sarcoma [27,30]. Despite the broad-spectrum antitumor activity of PTX and CPT, their clinical applications are hampered by their poor aqueous solubility, limited bioavailability, cellular permeability, lack of tumor selectivity, and serious adverse effects (e.g., myelosuppression and gastrointestinal toxicity) following intravenous administration [30]. Several efforts have been devoted to the development of active formulations of PTX and CPT to improve their water solubility and pharmacokinetic, cell membrane permeability, and tissue selectivity. Nanoparticles, solid lipid nanoparticles, liposomal formulations, hyperbranched block-copolymers, dendrimers, PEGylated polymeric materials, quantum dots, polymeric micelles, and PEGylated poly(L-lysine) (PLL) have shown success, and some of these formulations entered clinical trials [22,30-40]. 
In continuation of our efforts to design CPP-drug conjugates based on the CPPs containing tryptophan and arginine residues, herein, we report the conjugation of PTX and CPT to the [W(RW $\left.{ }_{4} \mathrm{~K}\right]$ peptide and compare the antiproliferative activity of the free drugs with the drug-peptide conjugate in breast cancer cell line MCF-7.

\section{Results and Discussion}

\subsection{Synthesis of Cyclic Peptide $\left[(W R)_{4} K(\beta A l a)\right]$ and Its Functionalization}

Cyclic peptide $\left[\mathrm{W}(\mathrm{WR})_{4} \mathrm{~K}(\beta \mathrm{Ala})\right]$ contains alternative L-tryptophan $(\mathrm{W})$ and L-arginine (R) residues and was used in previous studies for the delivery of Cur and Dox to different cancer cell lines [21,26]. [W(WR $)_{4} \mathrm{~K}(\beta$ Ala) $]$ (P1) was prepared through the $\mathrm{Fmoc} / \mathrm{tBu}$ solid-phase chemistry using appropriate Fmoc-protected amino acids and the orthogonally protected lysine residue with the Dde group [21,26]. The protected cyclic peptide $\left[(\mathrm{W}(\mathrm{Boc}) \mathrm{R}(\mathrm{Pbf}))_{4} \mathrm{~W}(\mathrm{Boc}) \mathrm{K}(\beta \mathrm{Ala}-\mathrm{Boc})\right]$ was obtained by the cyclization of the side chain-protected linear peptide (HOOC-((W(Boc) $\mathrm{R}(\mathrm{Pbf}))_{4} \mathrm{~W}(\mathrm{Boc}) \mathrm{K}\left(\beta\right.$ Ala-Boc) $\left.-\mathrm{NH}_{2}\right)$ in anhydrous DMF/DCM mixture $(4: 1, v / v)$ using HOAt/DIC as activating agents. The completion of cyclization was confirmed by checking the mass of a crude sample taken from the reaction mixture as described in Section 3.2.1. The cleavage of the protecting group using reagent " $\mathrm{R}$ " afforded the cyclic peptide $\mathrm{P} 1$ with the exact mass of 1754.0300 corresponding to $\left[\mathrm{M}+\mathrm{H}^{+}\right]$(see Supplementary Materials). The thiol functionality was introduced to the cyclic peptide with the coupling of tritylthiopropionic acid in DMF/DIPEA/HBTU. Completion of the reaction was confirmed by mass spectroscopy. The trityl protecting group was cleaved from the thiol group using a mixture of TFA/TIS/ $\mathrm{H}_{2} \mathrm{O}$. MALDI mass spectroscopy revealed the exact mass at $1842.8826[\mathrm{M}-\mathrm{H}]^{-}$for P2. The last step of peptide functionalization was performed using 2-(pyridinyldithio)ethaneamine which reacted with the cyclic peptide P2. MALDI analysis showed the existence of a single peak at $1917.9098[\mathrm{M}+\mathrm{H}]^{+}$(see Supplementary Materials) for the final product (P3) as depicted in Scheme 1. P1 was used for the conjugation with both PTX-2-O-hemiglutarate (Scheme 2) and CPT-20-O-chloroformate (Scheme 3) to afford PTX-1 and CPT1, respectively. P3 was used for conjugation with CPT-20-O-chloroformate to afford CPT2 (Scheme 3) as described below.

\subsection{Coupling Hydrophobic Drugs to $\left[W(W R)_{4} K(\beta A l a)\right]$}

\section{Coupling of PTX to $\left[\mathrm{W}(\mathrm{WR})_{4} \mathrm{~K}(\beta \mathrm{Ala})\right]$}

PTX is not amenable for coupling unless it is chemically modified. Although PTX has 2'-hydroxyl and 7-hydroxyl groups which are more susceptible to the chemical modifications. However, the 2'-hydroxyl group has superior reactivity than that at the 7-hydroxyl group due to the steric hindrance at this position [38]. Therefore, PTX was functionalized by its reaction with glutaric anhydride, which was reacted with the hydroxyl group at $\mathrm{C}^{\prime}{ }^{\prime}$ with the ester linkage. The resulted 2'-O-hemiglutarate was conjugated with [W(WR $\left.)_{4} \mathrm{~K}(\beta \mathrm{Ala})\right]$ (P1) through the amide linkage using PyBOP, $\mathrm{HOBt}$, and DIPEA under $\mathrm{N}_{2}$ at room temperature. The conjugate was purified by RP-HPLC and analyzed by MALDI that showed a single peak at 2703.9563 corresponding to $[\mathrm{M}+\mathrm{H}]^{+}$(see Supplementary Materials) for the $\left[\mathrm{W}(\mathrm{WR})_{4} \mathrm{~K}(\beta\right.$ Ala-hemiglutarate-2-O-PTX)] conjugate (PTX1), as demonstrated in Scheme 2.

Similarly, CPT was conjugated to the $\left[\mathrm{W}(\mathrm{WR})_{4} \mathrm{~K}(\beta \mathrm{Ala})\right](\mathrm{P} 1)$ through an amide bond. Initially, CPT with a C20-chloroformate functional group was prepared by the treatment of $\mathrm{CPT}$ with triphosgene in the presence of DMAP. CPT-20-O-chloroformate was conjugated with P1 through two different approaches; the first approach was through the $\mathrm{pH}$-labile carbonate bridge, which bound directly to the free $\beta$-alanyl amino group of the cyclic peptide in DMF using a catalytic amount of DIPEA, as depicted in Scheme 3, to afford carbamate conjugate CPT1. The second approach depends on the reductive-cleavage for the disulfide bridge and hydrolysis of carbonate linkage (the dual response approach) in compound CPT2. Compound P3 was reacted with CPT-20-O-chloroformate in the 
presence of DIPEA to afford CPT2. It was expected that in the second approach, the disulfide bridge in $\left(\left[\mathrm{W}(\mathrm{WR})_{4} \mathrm{~K}(\beta \mathrm{Ala})-S-S-\mathrm{CPT}\right]\right.$ would be cleaved via reduction of the disulfide bridge by the intracellular glutathione (GSH). Whereas, the concentration of GSH in the tumor tissue is 4 times higher than that of the normal tissues [40]. Darwish et al. [41] have previously reported the impact of a disulfide bridge in increasing the cytotoxic activity of Dox conjugated to [C(WR $)_{4} \mathrm{~K}$ ] when investigated in HEK-293, HT-1080, and SKOV-3 cells as compared to Dox after $72 \mathrm{~h}$ incubation. The mechanism affording the thiol-containing CPT followed by the carbonate bond cleavage liberating thiazolidinone and CPT and five-membered thiolactam was demonstrated by Henne et al. and Zhang et al. [39,40].
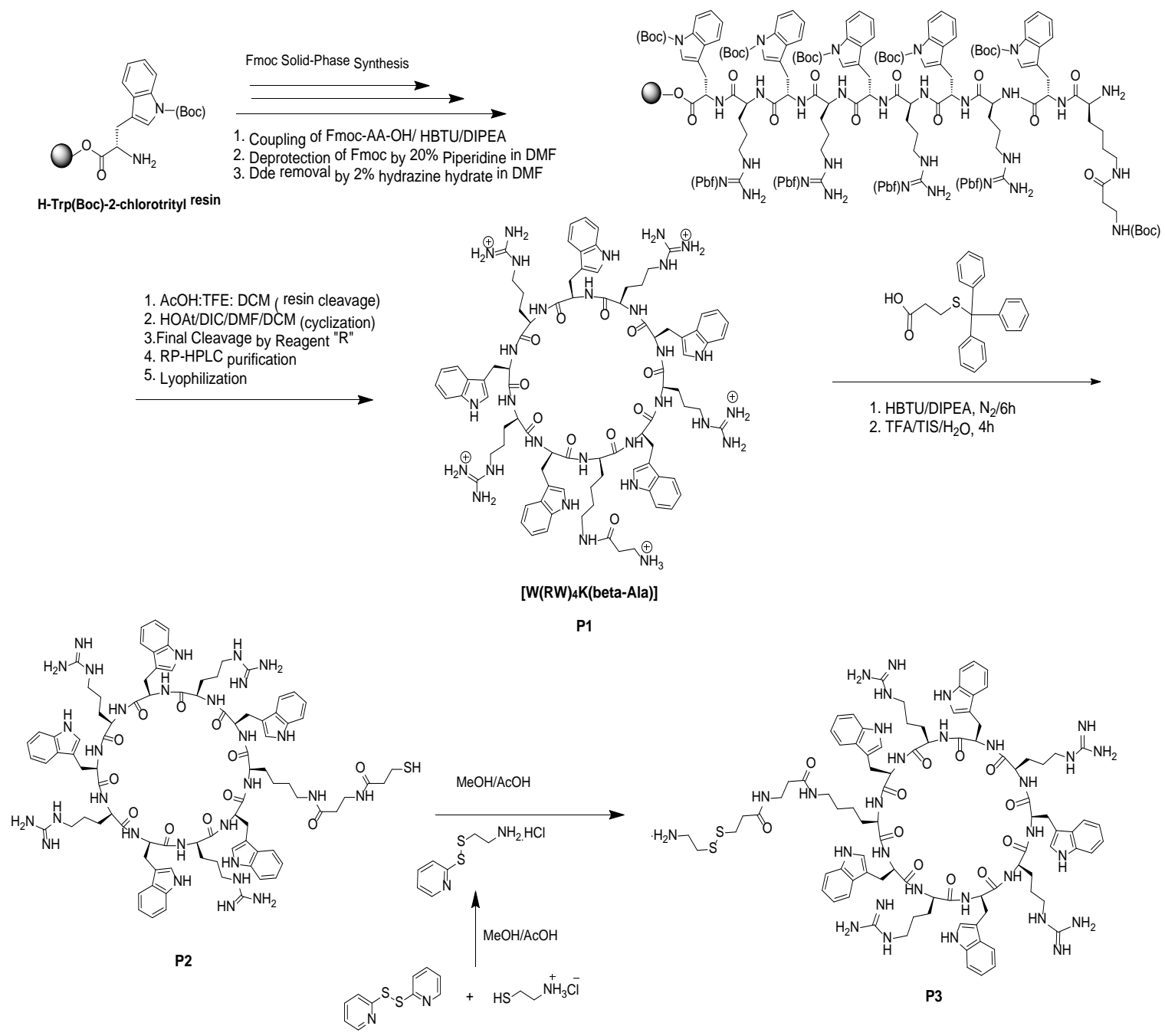

P3

Scheme 1. Synthesis of $\left[\mathrm{W}(\mathrm{WR})_{4} \mathrm{~K}(\beta \mathrm{Ala})\right]$ and its functionalization with tritylthiopropionic acid and 2-(pyridinyldithio)ethaneamine.

\subsection{Biological Activity}

Our previous studies revealed that $\left[\mathrm{W}(\mathrm{WR})_{4} \mathrm{~K}(\beta \mathrm{Ala})\right]$ did not show any significant cytotoxicity up to $10 \mu \mathrm{M}$ on MDA-MB-468, HCT-116, CCRF-CEM, and SK-OV-3 [21,25,26]. Herein, the antiproliferative activity of conjugate was evaluated in the presence of the human breast adenocarcinoma (MCF-7) cells. Among breast cancer cells, MCF-7 ones were selected to be tested for this assay due to their significant response to microtubule-targeting drugs [42,43]. 


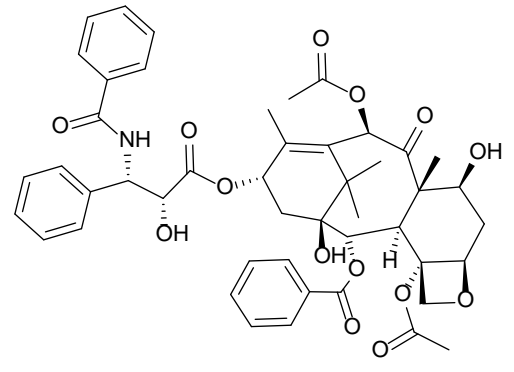

PTX

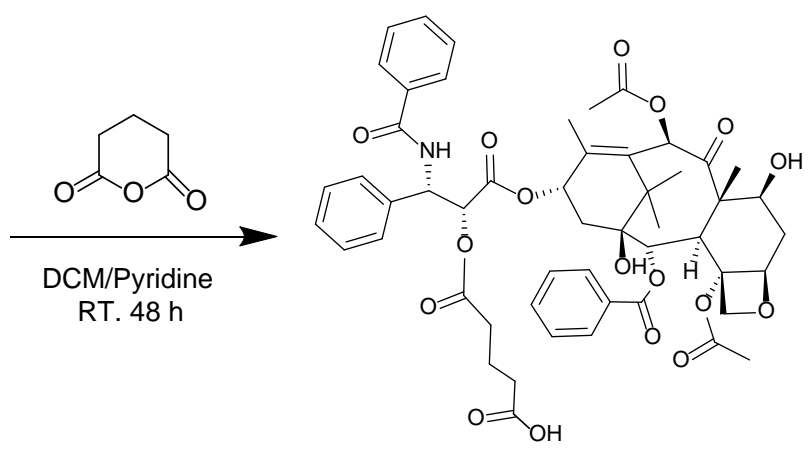

PTX-2-O-hemiglutarate
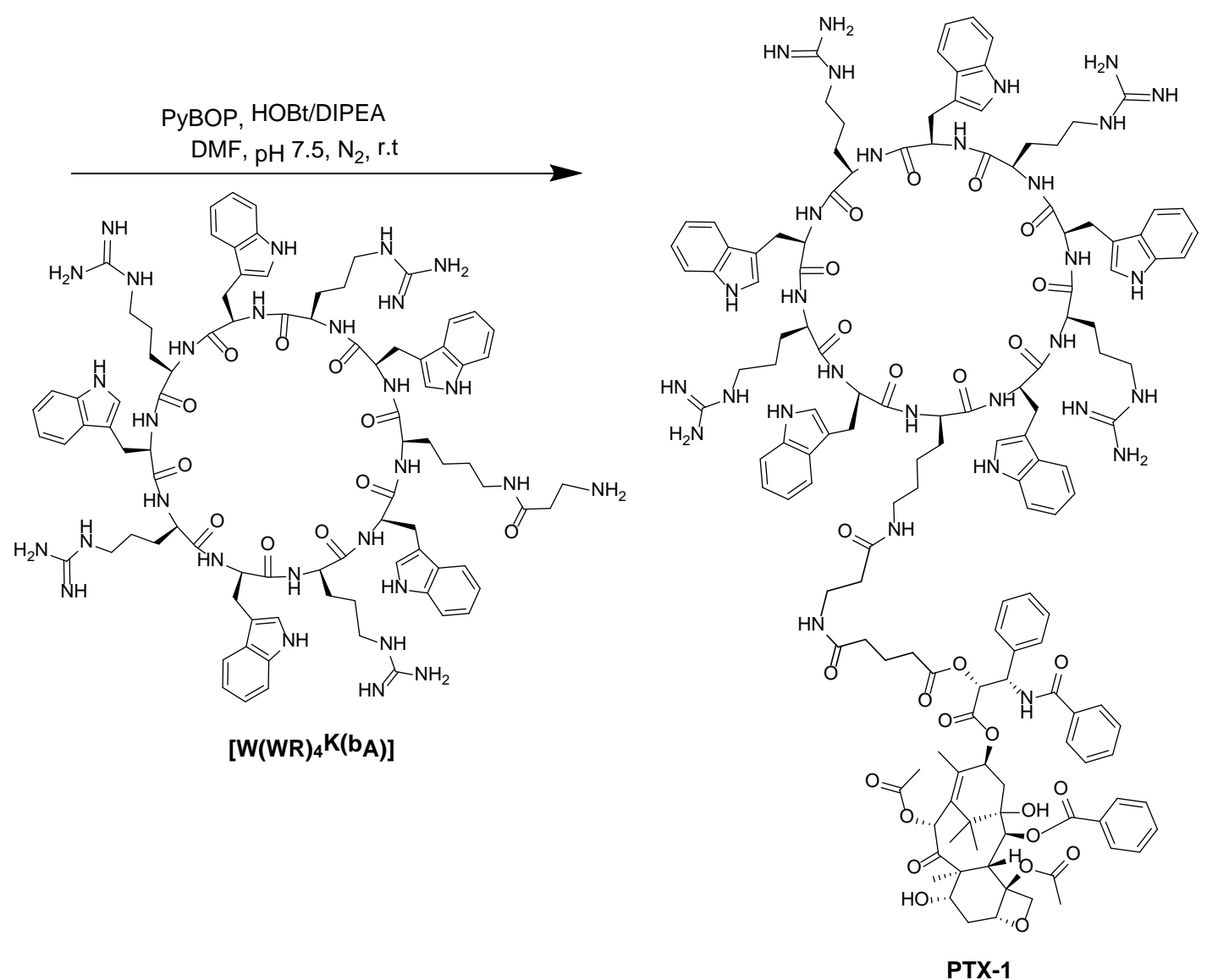

Scheme 2. Synthesis of PTX-O-hemiglutarate and its conjugation with $\left[\mathrm{W}(\mathrm{WR})_{4} \mathrm{~K}(\beta \mathrm{Ala})\right]$.

Consequently, the concentration of $5 \mu \mathrm{M}$ was selected to study the antiproliferation activity of the drug-peptide conjugates. Preliminary cytotoxicity investigation against MCF-7 cell lines showed that both CPT and PTX reduced the cell proliferation of MCF-7 cells at $5 \mu \mathrm{M}$ by $\sim 68 \%$ and $39 \%$, respectively, after $72 \mathrm{~h}$ using MTT assay. We have previously shown that the peptide-drug conjugates containing doxorubicin and a similar cyclic peptide containing tryptophan and arginine were cleaved by $99 \%$ in the presence of the cancer cells after $72 \mathrm{~h}$ of incubation as shown by HPLC analysis [26]. Therefore, $72 \mathrm{~h}$ was selected for the incubation of the conjugates in in vitro assays. Further analysis in a shorter time may be beneficial for comparative studies. Although the cells could be incubated with drugs for a longer period, the other elements such as sedimentation of the drug would have complicated the antiproliferative outcomes. 

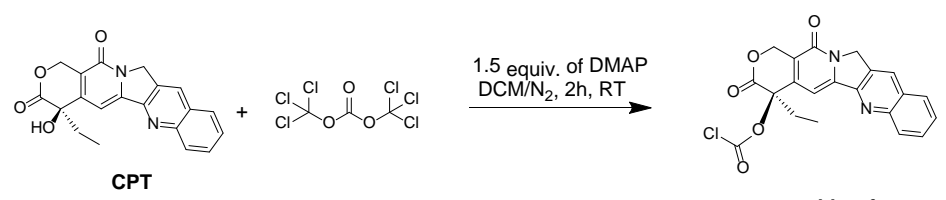

CPT-20-O-chloroformate
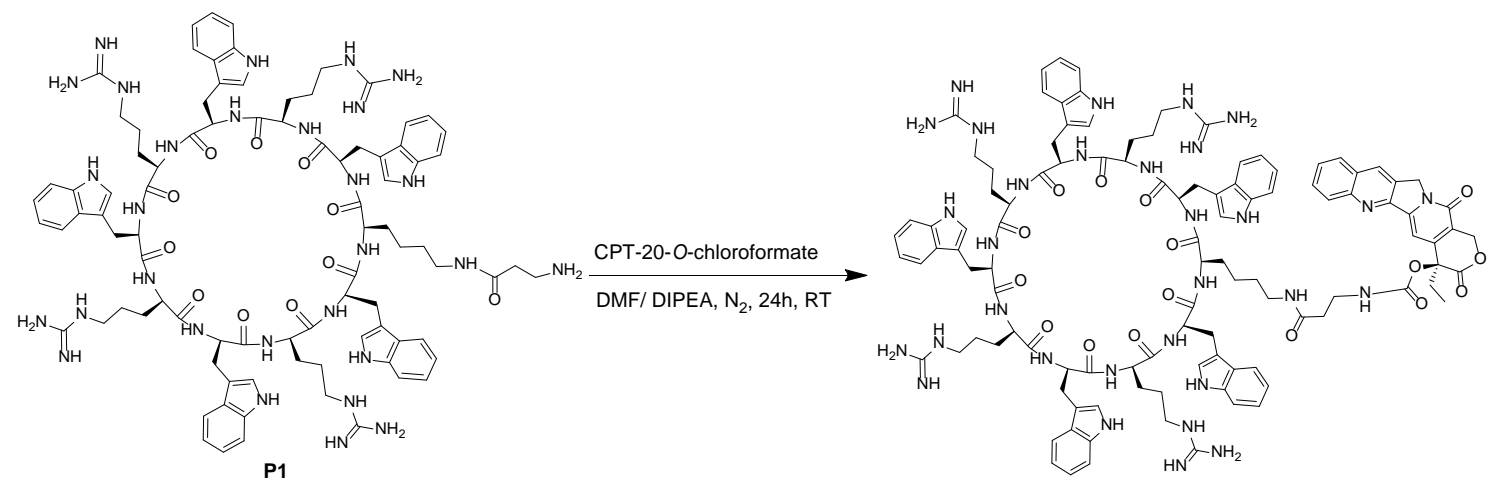

CPT 1
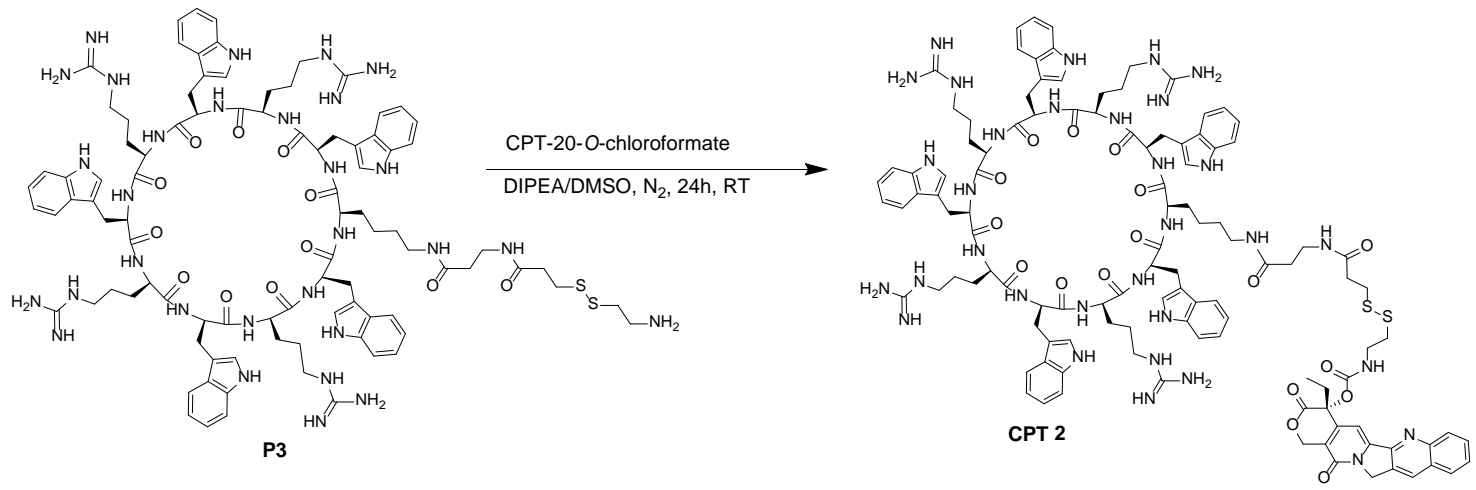

Scheme 3. Synthesis of CPT-20-O-chloroformate and its conjugation with $\left[\mathrm{W}(\mathrm{WR})_{4} \mathrm{~K}(\beta \mathrm{Ala})\right]$ and $\left[(\mathrm{WR})_{4} \mathrm{~W} \mathrm{~K}(\beta\right.$ Ala-thiopropionyl-S-S-ethaneamine $\left.)\right]$ peptide.

Antiproliferative results showed that PTX1 inhibited cell proliferation by $18.7 \%$. The anti-proliferative activity of CPT1 was diminished by 1.9-fold as compared to CPT whereas the activity of CPT2 was comparable to CPT, since CPT2 reduced the cell viability to $61 \%$ as shown in Figure 1. Since these compounds were peptide-drug conjugates, it was expected that the release of the parent drug would generate the cytotoxic effect. However, PTX1 was not very cytotoxic presumably due to the stability of the conjugate. Among CPT conjugates, CPT2 exhibited higher antiproliferative activity, due to the enhanced release of CPT. We presume that disulfide linker is reduced leading to the release of active CPT from the conjugate. CPT1 and PTX1 conjugates had less activity than the corresponding parent analogs since they act as inactive prodrugs and may behave differently on longer incubation time. The cytotoxicity of PTX and PTX1 was further evaluated in the normal human embryonic kidney cells (HEK-293) at $5 \mu \mathrm{M}$ which showed reduced cell proliferation by $\sim 34 \%$ and $18 \%$, respectively, after $72 \mathrm{~h}$ using MTT assay, as shown in Figure 2. The lower cytotoxicity of conjugate PTX1 as compared to PTX in the normal cell lines could be due to slower hydrolysis of PTX from conjugate PTX1. 


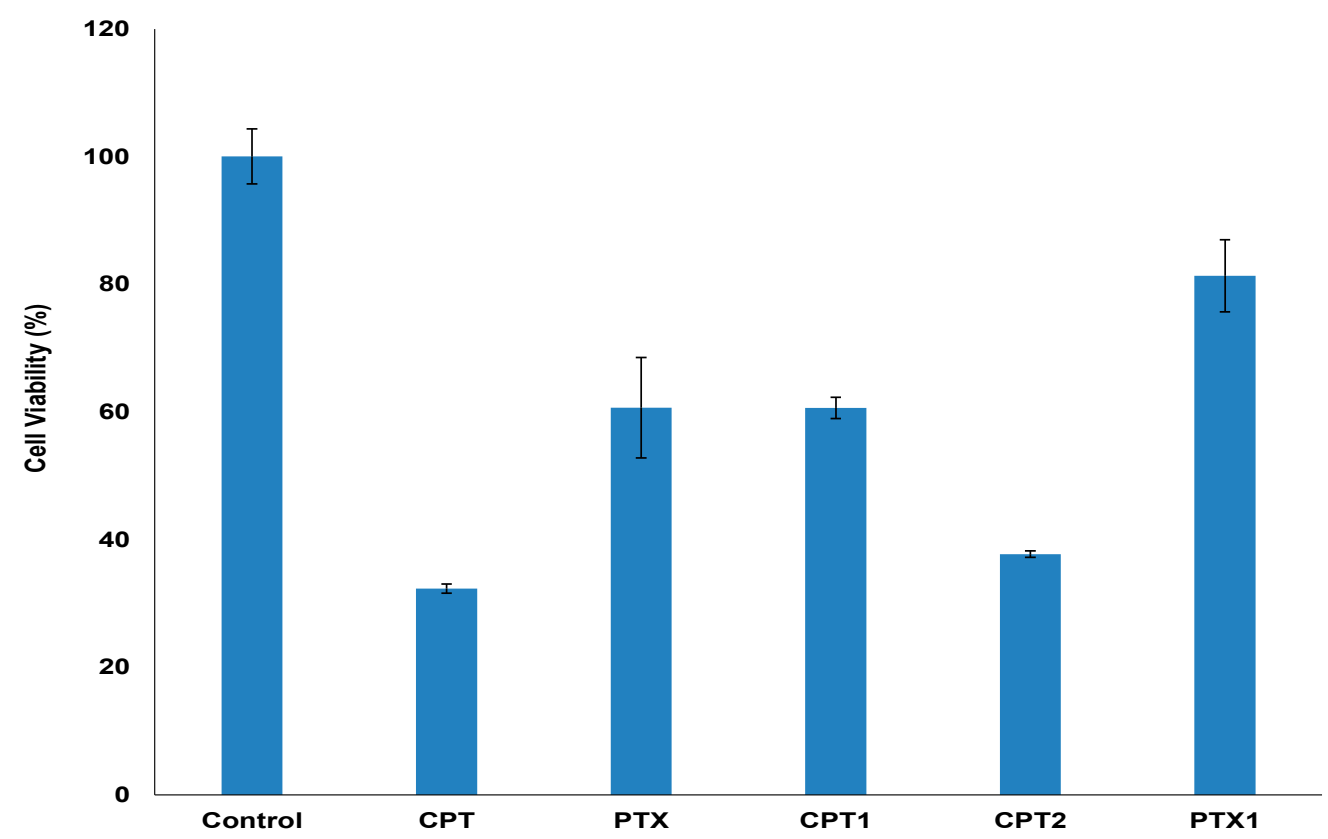

Figure 1. The antiproliferative activity of camptothecin (CPT), paclitaxel (PTX), and their conjugates at $(5 \mu \mathrm{M})$ concentration in MCF-7 cells after $72 \mathrm{~h}$ incubation.

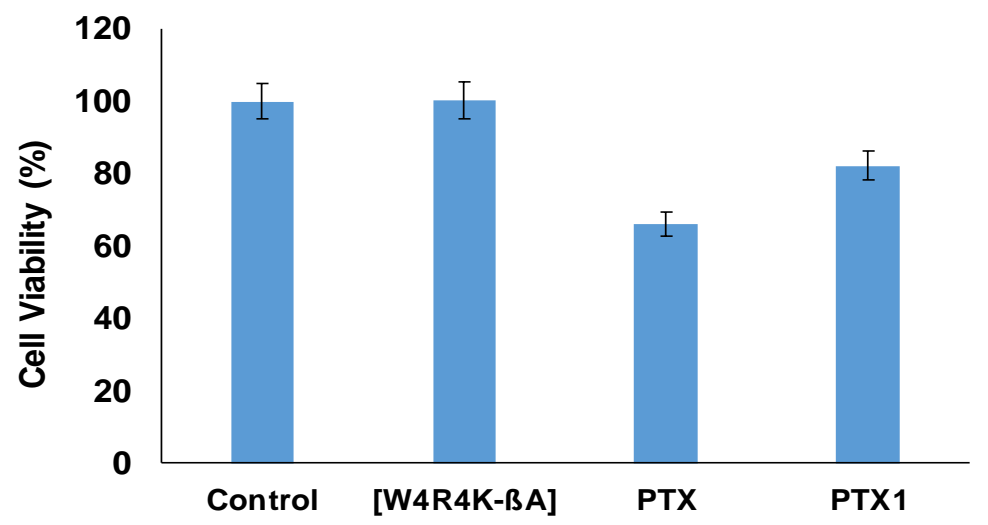

Figure 2. The antiproliferative activity of PTX and PTX1 at $(5 \mu \mathrm{M})$ concentration in HEK-298 cell line after $72 \mathrm{~h}$ incubation.

\section{Materials and Methods}

\subsection{Materials}

All required organic solvents were purchased from Wilkem Scientific (Pawtucket, RI, USA). The Fmoc-protected building block of amino acids, including Fmoc-Trp(Boc)-OH, Fmoc-Arg (Pbf)-OH, Dde-K(Boc)-OH, Boc- $\beta$ Ala-OH, 3-(tritylthio)propionic acid, and H-Trp(Boc)-2-chlorotrityl resin, were purchased from Chem-Impex International Inc. (Wood Dale, IL, USA). Hydroxy-7azabenzotriazole (HOAT), 1,3-diisopropylcarbodiimide (DIC), $O$-(benzotriazole-1-yl)- $N, N, N^{\prime}, N^{\prime}$ tetramethyluroniumhexafluorophosphate (HBTU), benzotriazol-1-yloxytripyrrolidinophosphonium hexafluorophosphate (PyBOP), and hydroxybenzotriazole (HOBt), glutaric anhydride (95\%), triphosgene (99\%), 4-dimethylaminopyridine (DMAP, 99\%), N,N-diisopropylethylamine (DIPEA), triethylamine (TEA), $\beta$-mercaptoethylamine hydrochloride (cystamine hydrochloride), and 2,2'-dithiodipyridine were purchased from Sigma-Aldrich Chemical Co. (Milwaukee, WI, USA). Camptothecin (CPT) was purchased from Santa Cruz Biotech, Inc. (Dallas, TX, USA) and Paclitaxel (PTX) was purchased from Euroasias Group Inc. (Woodbridge, NJ, USA). 


\subsection{Methods}

\subsubsection{Synthesis of Cyclic Peptide $\left[\mathrm{W}(\mathrm{RW})_{4} \mathrm{~K}(\beta \mathrm{Ala})\right](\mathrm{P} 1)$}

The linear peptide with protected side chains was prepared using $\mathrm{Fmoc} / \mathrm{tBu}$ chemistry. The peptide sequence was assembled on the H-Trp(Boc)-2-chlorotrityl resin (513 mg, $0.78 \mathrm{mmol} / \mathrm{g}$, $0.40 \mathrm{mM}$ ). After assembling the sequence, the Dde protecting group at the lysine $\alpha$-amino group was removed by agitating with a solution of hydrazine monohydrate in DMF $(2 \% v / v, 3 \times 25 \mathrm{~mL}$, $10 \mathrm{~min})$. Then, the resin was washed with $\mathrm{DMF}(1 \mathrm{~min} \times 2)$ and DCM $(1 \mathrm{~min} \times 2)$. The peptide was cleaved from the peptidyl resin using a mixture of acetic acid/trifluoroethanol (TFE)/DCM $(1: 2: 7, v / v / v)$ by stirring for $2 \mathrm{~h}$ at room temperature to afford the linear peptide with protected side chains. The peptide was collected by filtration and washed with DCM $(3 \times 15 \mathrm{~mL})$. The filtrate containing the peptide was evaporated under reduced pressure. To remove acetic acid from the cleaved peptide, the peptide was re-dissolved in $25 \mathrm{~mL}$ of DCM and precipitated with $50 \mathrm{~mL}$ of hexane, and the process was repeated four times until the peptide was completely dried and acetic acid was completely removed. The protected linear peptide was obtained as a solid white powder that was dried under vacuum overnight. The cyclization of the linear peptide was carried out by dissolving the peptide in DMF/DCM mixture $(250 \mathrm{~mL}, 4: 1 \mathrm{v} / \mathrm{v})$. Then HOAt (223 $\mathrm{mg}, 1.64 \mathrm{mmol}, 4 \mathrm{equiv})$ and DIC $(290 \mu \mathrm{L}, 1.86 \mathrm{mmol}, 4.5$ equiv) were added to the peptide solution. The mixture was stirred at room temperature for $12 \mathrm{~h}$. The completion of the cyclization was confirmed with mass checked by MALDI-TOF(shown in the Supplementary Materials). After the reaction was completed, the solvents were removed under reduced pressure using a rotary evaporator. The cleavage of the protecting groups from the amino acid side chains was carried out by adding reagent " $\mathrm{R}$ " containing trifluoroacetic acid (TFA)/thioanisole/ethanedithiol(EDT)/anisole (90:5:3:2, v/v/v/v, $25 \mathrm{~mL}$ ) to the cyclic peptide. The mixture was shaken at room temperature for $6 \mathrm{~h}$, and cold ether was added to precipitate the crude peptide. The peptide was collected and purified by reversed-phase Hitachi HPLC (L-2455) using a C18 column (Waters XBridgeTM BEH130 Prep C18 OBDTM $10 \mu$ m ODS reversed-phase column) $(2.1 \times 25 \mathrm{~cm})$ using a gradient system of acetonitrile/water containing $0.1 \%$ TFA to yield $(\sim 40 \%)$ the cyclic peptide [W(WR $\left.)_{4} \mathrm{~K}(\beta \mathrm{Ala})\right]$. MALDI-TOF $(\mathrm{m} / \mathrm{z})\left[\mathrm{C}_{88} \mathrm{H}_{115} \mathrm{~N}_{29} \mathrm{O}_{11}\right]$ : calcd 1753.9331; found $1755.0300[\mathrm{M}+2 \mathrm{H}]^{+}, 1792.9736[\mathrm{M}+\mathrm{K}]^{+}$(shown in Supplementary Materials).

3.2.2. Synthesis of $\left[(\mathrm{WR})_{4} \mathrm{WK}(\beta \mathrm{Ala}\right.$-Thiopropionic acid $\left.)\right](\mathrm{P} 2)$ and $\left[(\mathrm{WR})_{4} \mathrm{WK}(\beta \mathrm{Ala}-\mathrm{Thiopropionyl-}\right.$ ethaneamine] (P3)

$\left[\mathrm{W}(\mathrm{WR})_{4} \mathrm{~K}(\beta \mathrm{Ala})\right]$ peptide $(26.30 \mathrm{mg}, 0.015 \mathrm{mmol})$ was dissolved in $1 \mathrm{~mL}$ of anhydrous $\mathrm{DMF}$, then a solution of 3-(tritylthio)propionic acid $(6.1 \mathrm{mg}, 0.0175 \mathrm{mmol}, 1.16$ equiv) dissolved in $1 \mathrm{~mL}$ of DMF containing DIPEA (15.7 $\mu \mathrm{L}, 6$ equiv), and HBTU $(6.6 \mathrm{mg}, 0.0175 \mathrm{mmol})$ were added to the peptide solution, and the stirring was continued for $6 \mathrm{~h}$ under $\mathrm{N}_{2}$ at room temperature. After the reaction was completed, the solvent was evaporated under reduced pressure until complete dryness. The dry solid peptide was treated by a mixture of TFA/triisopropyl silane (TIS)/ $\mathrm{H}_{2} \mathrm{O}(10 \mathrm{~mL}, 7: 2: 1, v / v / v)$ and stirred at room temperature for $4 \mathrm{~h}$ to cleave the trityl group. Then the peptide was precipitated with cold diethyl ether and centrifuged, to yield the cyclic peptide [(WR $)_{4} \mathrm{WK}(\beta$ Ala-thiopropionic acid $\left.)\right]$ (P2) (23.3 mg, 93\% yield): MALDI-TOF (m/z) [ $\left.\mathrm{C}_{91} \mathrm{H}_{119} \mathrm{~N}_{29} \mathrm{O}_{12} \mathrm{~S}\right]$ : calcd 1841.9314; found 1842.8826 $[\mathrm{M}+\mathrm{H}]^{+}, 1864.8585[\mathrm{M}+\mathrm{Na}]$ (shown in Supplementary Materials).

The peptide $\left[(\mathrm{WR})_{4} \mathrm{WK}(\beta\right.$ Ala-thiopropionic acid $\left.)\right] \mathbf{P 2}(20 \mathrm{mg}, 0.011 \mathrm{mmol})$ containing free thiol group was further functionalized by reaction with 2-(pyridinyldithio)-ethaneamine hydrochloride ( $7.35 \mathrm{mg}, 0.033 \mathrm{mmol}, 3$ equiv) prepared using cystamine and dithiopyridine according to the method described by Zugates et al. [37] in methanol containing a catalytic amount of acetic acid. The reaction was stirred overnight at room temperature, and then the peptide (P3) was collected by precipitation with cold ether and purified by reversed-phase HPLC as mentioned above. The yield was $87.75 \%$ (17.55 mg). MALDI-TOF $(m / z)\left[\mathrm{C}_{93} \mathrm{H}_{124} \mathrm{~N}_{30} \mathrm{O}_{12} \mathrm{~S}_{2}\right]$ : calcd 1916.9456; found $1917.9089[\mathrm{M}+\mathrm{H}]^{+}$, $1941.9098[\mathrm{M}+\mathrm{Na}]^{+}$(shown in Supplementary Materials). 


\subsubsection{Synthesis of Paclitaxel-2-O-Hemiglutarate}

Paclitaxel-2-O-hemiglutarate was prepared according to the method described by Sundaram et al. [38]. In brief, paclitaxel $(100 \mathrm{mg}, 0.117 \mathrm{mM})$ and glutaric anhydride $(13.70 \mathrm{mg}$, $0.12 \mathrm{mM}$ ) were dissolved in $15 \mathrm{~mL}$ of $\mathrm{DCM}$, and $10 \mu \mathrm{L}$ of dry pyridine was added to the reaction mixture as a base catalyst. The reaction was stirred under nitrogen for $48 \mathrm{~h}$ at room temperature. The progress of the reaction was monitored by TLC using hexane:ethyl acetate $(7: 3, v / v)$. The crude mixture was purified by silica gel chromatography. The compound was obtained as a white solid (76 mg, 95\% yield). HR-MS (ESI) $(m / z)\left[C_{52} \mathrm{H}_{57} \mathrm{NO}_{17}\right]$ : calcd 967.3626; found $968.3479[\mathrm{M}+\mathrm{H}]^{+}$.

3.2.4. General Procedure for the Synthesis of PTX-1 from Coupling of [W(WR $)_{4} \mathrm{~K}(\beta$ Ala $\left.)\right]$ Peptide with PTX-2-O-Hemiglutarate

PTX-2-O-hemiglutarate (1.2 equiv, $11.6 \mathrm{mg}, 1.2 \mathrm{mM}$ ), benzotriazol-1-yloxytripyrrolidinophosphoniumhexafluorophosphate (PyBOP, 1.5 equiv, $7.81 \mathrm{mg}, 0.015 \mathrm{mM}$ ), and 1-hydroxybenzotriazole (HOBt, 2.5 equiv, $3.38 \mathrm{mg}, 0.025 \mathrm{mM}$ ) were mixed together in a glass vial under nitrogen atmosphere using $2 \mathrm{~mL}$ of anhydrous DMF to activate the carboxylate group of the hemiglutarate moiety for $10 \mathrm{~min}$. Then a solution of $\left[\mathrm{W}(\mathrm{WR})_{4} \mathrm{~K}(\beta\right.$ Ala $\left.)\right]$ peptide (1 equiv, $\left.17.54 \mathrm{mg}, 1 \mathrm{mM}\right)$ in DMF containing DIPEA ( 3 equiv, $5 \mu \mathrm{L}, 0.03 \mathrm{mM}$ ) was added to the activated PTX-2-O-hemiglutarate mixture dropwise over $10 \mathrm{~min}$. The reaction mixture was stirred for $2-3 \mathrm{~h}$ in the dark under $\mathrm{N}_{2}$ gas. The progress of conjugation was monitored by checking the mass of a small sample taken from the reaction mixture by MALDI-TOF to confirm the formation of the PTX-peptide conjugate. After the reaction was completed, the crude product was precipitated by adding cold diethyl ether and centrifuged. The peptide was dried under nitrogen gas, dissolved in acetonitrile/water $(50 \% v / v)$, and purified by RP-HPLC affording [W(WR $)_{4} \mathrm{~K}(\beta$ Ala-hemiglutarate-2-O-PTX)] conjugate (PTX-1), which was lyophilized (5.5 mg, 18.9\% yield). MALDI-TOF $(m / z)\left[\mathrm{C}_{140} \mathrm{H}_{170} \mathrm{~N}_{30} \mathrm{O}_{27}\right]$ : calcd 2703.2852; found 2703.9563 [M] $]^{+}$(shown in Supplementary Materials).

\subsubsection{Synthesis of Camptothecin-20-O-Chloroformate}

Camptothecin-20-O-chloroformate was prepared as described by Henne et al. [39]. In brief, CPT (863 mg, $2.5 \mathrm{mM}$ ) and DMAP (763 mg, $6.25 \mathrm{mM}$ ) were dissolved in $15 \mathrm{~mL}$ of dry $\mathrm{CH}_{2} \mathrm{Cl}_{2}$ under $\mathrm{N}_{2}$ atmosphere. Triphosgene $(0.250 \mathrm{mg}, 0.84 \mathrm{mM})$ dissolved in $5 \mathrm{~mL}$ of dry DCM was added to CPT solution at $0{ }^{\circ} \mathrm{C}$. The mixture was stirred for a further $60 \mathrm{~min}$. Then the reaction mixture was dissolved in $50 \mathrm{~mL}$ of DCM and extracted by addition of $1.0 \mathrm{M} \mathrm{HCl}$ solution $(2 \times 50 \mathrm{~mL})$, and brine $(2 \times 50 \mathrm{~mL})$. The organic layer was collected and dried over anhydrous $\mathrm{Na}_{2} \mathrm{SO}_{4}$. $\mathrm{DCM}$ was evaporated and used without further purification to give a pale-yellow powder $(761 \mathrm{mg}, 88 \%$ yield).

\subsubsection{Synthesis of $\mathrm{CPT} 1$ from Coupling of $\left[\mathrm{W}(\mathrm{WR})_{4} \mathrm{~K}(\beta \mathrm{Ala})\right]$ Peptide with CPT-20-O-Chloroformate}

$\left[\mathrm{W}(\mathrm{WR})_{4} \mathrm{~K}(\beta \mathrm{Ala})\right]$ (1 equiv, $\left.17.54 \mathrm{mg}, 1 \mathrm{mM}\right)$ peptide was dissolved in $1 \mathrm{~mL}$ of anhydrous DMF, and CPT-20-O-chloroformate (1.2 equiv, $4.92 \mathrm{mg}, 1.2 \mathrm{mM}$ ) dissolved in $5 \mathrm{~mL}$ of anhydrous DCM containing (3 equiv, $5 \mu \mathrm{L}, 0.03 \mathrm{mM}$ ) of DIPEA was added to the peptide solution, and the reaction was continued for $24 \mathrm{~h}$. The progress of conjugation was monitored by checking the mass using MALDI-TOF. Once the reaction was completed, the crude product was precipitated by adding cold diethyl ether and centrifuged, dried under $\mathrm{N}_{2}$. The dried solid compound was dissolved in acetonitrile/water $(50 \% v / v)$ and purified by RP-HPLC. The purified CPT-20-O-formyl-[W(WR $\left.)_{4} \mathrm{~K}(\beta \mathrm{Ala})\right]$ (CPT1) conjugate was lyophilized $(7.56 \mathrm{mg}, 33.40 \%$ yield). MALDI-TOF $(m / z)\left[\mathrm{C}_{109} \mathrm{H}_{129} \mathrm{~N}_{31} \mathrm{O}_{16}\right]$ : calcd 2128.0234; found 2128.6907 [M] $^{+}$(shown in Supplementary Materials). 
3.2.7. Synthesis of CPT2 from Coupling of [(WR $)_{4} \mathrm{WK}(\beta$ Ala-thiopropionyl-S-S-ethaneamine)] with CPT-20-O-chloroformate

CPT-20-O-chloroformate (1.2 equiv, $4.92 \mathrm{mg}, 1.2 \mathrm{mM}$ ) was dissolved in $5 \mathrm{~mL}$ of anhydrous DCM containing DIPEA ( 3 equiv, $5 \mu \mathrm{L}, 0.03 \mathrm{mM}$ ). The peptide ( 1 equiv, $17.54 \mathrm{mg}, 0.1 \mathrm{mM}$ ) was dissolved in $1 \mathrm{~mL}$ of anhydrous DMSO and added dropwise over $10 \mathrm{~min}$ to CPT-20-O-chloroformate solution. The reaction mixture was stirred for $24 \mathrm{~h}$ at room temperature under $\mathrm{N}_{2}$, and the reaction progress was monitored using MALDI-TOF to check the formation of CPT-peptide conjugate. Once the reaction was completed, the crude product was precipitated by adding cold diethyl ether, centrifuged, and dried under $\mathrm{N}_{2}$. The dried solid compound was dissolved in acetonitrile/water $(50 \%, v / v)$ and purified by RP-HPLC (6.21 mg, 25.8\% yield). The purified [W(WR $)_{4} \mathrm{~K}(\beta$ Ala-formyl-O-20-CPT)] (CPT2) conjugate was lyophilized. MALDI-TOF $(\mathrm{m} / \mathrm{z})\left[\mathrm{C}_{114} \mathrm{H}_{138} \mathrm{~N}_{32} \mathrm{O}_{17} \mathrm{~S}_{2}\right]$ : calcd 2291.0359; found $2291.9724[\mathrm{M}]^{+}$(shown in Supplementary Materials).

\subsubsection{Cell Culture}

Human breast cancer cell line (MCF-7, ATCC\# HTB-22 ${ }^{\mathrm{TM}}$ ) cells and human embryonic kidney cells (HEK-293, ATCC\# CRL-1573) were purchased from the American Type Culture Collection (Manassas, VA, USA). All MCF-7 cells were cultured using $75 \mathrm{~cm}^{2}$ cell culture flasks. A complete Eagle's minimum essential medium (EMEM) $\left(\right.$ ATCC $^{\circledR} 30-2003^{\mathrm{TM}}$ ) containing fetal bovine serum (FBS, $10 \%)$, and penicillin-streptomycin solution (1\%, penicillin (10,000 units) and streptomycin (10 mg in $0.9 \% \mathrm{NaCl})$ were used under the atmosphere of $\mathrm{CO}_{2}(5 \%)$ and air $(95 \%)$ at $37^{\circ} \mathrm{C}$.

\subsubsection{Antiproliferative Assay}

The comparative antiproliferative assay was conducted using the MTS cell viability method to evaluate the potency of the conjugates to inhibit the proliferation of MCF-7 breast cancer cells and HEK-293 normal embryonic kidney cells. The cells were seeded $(5000 / 0.1 \mathrm{~mL})$ in each well using a 96-well plate. The MCF-7 cells were treated with PTX and CPT drugs and their corresponding conjugates in the medium. The final concentrations of all the compounds were adjusted to be $5 \mu \mathrm{M}$. Cells were incubated with the treatments for $4 \mathrm{~h}$. Then, the treatments were removed and replaced by the fresh medium and incubated for a further $72 \mathrm{~h}$. A similar treatment was followed for the HEK-293 cell line with PTX1, PTX, and cyclic peptide $\left[\mathrm{W}(\mathrm{WR})_{4} \mathrm{~K}(\beta\right.$ Ala $\left.)\right]$ at $5 \mu \mathrm{M}$. The CellTiter 96 aqueous solution (Promega, Madison, WI, USA) was used to measure the cell viability based on the fluorescence intensity of them at $490 \mathrm{~nm}$. Here, SpectraMax M2 microplate spectrophotometer was employed for the assay. The cell viability was calculated relatively based on the cell survival as [(OD value of cells treated with the test mixture of compounds) - (OD value of culture medium)]/[(OD value of control cells $)-(\mathrm{OD}$ value of culture medium) $] \times 100 \%$.

\section{Conclusion}

A cyclic cell-penetrating peptide $\left[\mathrm{W}(\mathrm{WR})_{4} \mathrm{~K}(\beta\right.$ Ala $\left.)\right]$ was synthesized and used as a molecular cargo for hydrophobic anticancer drugs CPT and PTX. The drugs, CPT and PTX, were functionalized with a linker and conjugated with the peptide. The conjugates showed better water solubility due to their attachment to $\left[\mathrm{W}(\mathrm{WR})_{4} \mathrm{~K}(\beta \mathrm{Ala})\right]$ which promises improved bioavailability and pharmacokinetic profiles. The antiproliferative activities of the peptide-drug conjugates were less than the free hydrophobic drugs in MCF-7 after $72 \mathrm{~h}$ incubation, which suggests the prodrug formation of CPT and PTX. The CPT conjugate named [W(WR $\left.)_{4} \mathrm{~K}-(\beta A l a)\right]-S-S-C P T(C P T 2)$ was found to be more cytotoxic when compared with $\left[\mathrm{W}(\mathrm{WR})_{4} \mathrm{~K}-(\beta \mathrm{Ala})\right]-\mathrm{CPT}(\mathrm{CPT} 1)$, suggesting the fast release of $\mathrm{CPT}$ analog in this conjugate. Future studies will be conducted to explore the potency of these conjugates on different cell lines and to understand the actual mechanism for the release of PTX and CPT from the peptide and improving the conjugation strategy of the drugs to the peptide. 
Supplementary Materials: The MALDI spectra of selected compounds are provided.

Author Contributions: R.K.T. and K.P. planned and designed the experiments; N.S.E.-S. and M.I.S. synthesized peptides, the drug modifications, and conjugation; A.N.S. and S.E.P. performed the cell assays; N.S.E.-S., K.P., and R.K.T. contributed reagents/materials/analysis tools; N.S.E.-S., K.P., and R.K.T. wrote the manuscript.

Acknowledgments: The authors greatly acknowledge financial support for this research from the Chapman University School of Pharmacy.

Conflicts of Interest: The authors declare no conflict of interest.

\section{References}

1. Bae, Y.H. Drug targeting and tumor heterogeneity. J. Control. Release 2009, 133, 1-3. [CrossRef] [PubMed]

2. Gullotti, E.; Yeo, Y. Extracellularly activated nanocarriers: A new paradigm of tumor targeted drug delivery. Mol. Pharm. 2009, 6, 1041-1051. [CrossRef] [PubMed]

3. Yamashita, F.; Hashida, M. Pharmacokinetic considerations for targeted drug delivery. Adv. Drug Deliv. Rev. 2013, 65, 139-147. [CrossRef] [PubMed]

4. Danhier, F.; Feron, O.; Préat, V. To exploit the tumor microenvironment: Passive and active tumor targeting of nanocarriers for anti-cancer drug delivery. J. Control. Release 2010, 148, 135-146. [CrossRef]

5. Muro, S. Challenges in design and characterization of ligand-targeted drug delivery systems. J. Control. Release 2012, 164, 125-137. [CrossRef]

6. Rosenblum, D.; Joshi, N.; Tao, W.; Karp, J.M.; Peer, D. Progress and challenges towards targeted delivery of cancer therapeutics. Nat. Commun. 2018, 9, 1410. [CrossRef]

7. Löwik, D.W.; Leunissen, E.H.P.; van den Heuvel, M.; Hansen, M.B.; van Hest, J.C. Stimulus responsive peptide-based materials. Chem. Soc. Rev. 2010, 39, 3394-3412. [CrossRef] [PubMed]

8. Myrberg, H.; Zhang, L.; Mäe, M.; Langel, Ü. Design of a tumor-homing cell-penetrating peptide. Bioconjug. Chem 2007, 19, 70-75. [CrossRef] [PubMed]

9. Luque-Ortega, J.R.; Hof, W.V.T.; Veerman, E.C.; Saugar, J.M.; Rivas, L. Human antimicrobial peptide histatin 5 is a cell-penetrating peptide targeting mitochondrial ATP synthesis in Leishmania. FASEB J. 2008, 22, 1817-1828. [CrossRef]

10. Derakhshankhah, H.; Jafari, S. Cell penetrating peptides: A concise review with emphasis on biomedical applications. Biomed. Pharmacother. 2018, 108, 1090-1096. [CrossRef] [PubMed]

11. Splith, K.; Neundorf, I. Antimicrobial peptides with cell-penetrating peptide properties and vice versa. Eur. Biophys. J. 2011, 40, 387-397. [CrossRef]

12. Vasconcelos, L.; Pärn, K.; Langel, Ü. Therapeutic potential of cell-penetrating peptides. Therap. Deliv. 2013, 4, 573-591. [CrossRef]

13. Reissmann, S. Cell penetration: Scope and limitations by the application of cell-penetrating peptides. J. Pept. Sci. 2014, 20, 760-784. [CrossRef]

14. Dong, H.; Hartgerink, J.D. Role of hydrophobic clusters in the stability of $\alpha$-helical coiled coils and their conversion to amyloid-like $\beta$-sheets. Biomacromolecules 2007, 8, 617-623. [CrossRef]

15. Mart, R.J.; Osborne, R.D.; Stevens, M.M.; Ulijn, R.V. Peptide-based stimuli-responsive biomaterials. Soft Matter 2006, 2, 822-835. [CrossRef]

16. El-Sayed, N.S.; Miyake, T.; Shirazi, A.; Park, S.; Clark, J.; Buchholz, S.; Parang, K.; Tiwari, R. Design, Synthesis, and Evaluation of Homochiral Peptides Containing Arginine and Histidine as Molecular Transporters. Molecules 2018, 23, 1590. [CrossRef]

17. Guidotti, G.; Brambilla, L.; Rossi, D. Cell-penetrating peptides: From basic research to clinics. Trends Pharmacol. Sci. 2017, 38, 406-424. [CrossRef]

18. Aroui, S.; Brahim, S.; Hamelin, J.; De Waard, M.; Bréard, J.; Kenani, A. Conjugation of doxorubicin to cell penetrating peptides sensitizes human breast MDA-MB 231 cancer cells to endogenous TRAIL-induced apoptosis. Apoptosis 2009, 14, 1352-1365. [CrossRef]

19. Zhang, W.; Song, J.; Zhang, B.; Liu, L.; Wang, K.; Wang, R. Design of acid-activated cell penetrating peptide for delivery of active molecules into cancer cells. Bioconj. Chem. 2011, 22, 1410-1415. [CrossRef]

20. Song, J.; Zhang, Y.; Zhang, W.; Chen, J.; Yang, X.; Ma, P.; Zhang, B.; Liu, B.; Ni, J.; Wang, R. Cell penetrating peptide TAT can kill cancer cells via membrane disruption after attachment of camptothecin. Peptides 2015, 63, 143-149. [CrossRef] 
21. Shirazi, A.N.; Salem El-Sayed, N.; Tiwari, R.K.; Tavakoli, K.; Parang, K. Cyclic peptide containing hydrophobic and positively charged residues as a drug delivery system for curcumin. Curr. Drug Deliv. 2016, 13, 409-417. [CrossRef]

22. Sharma, M.; El-Sayed, N.S.; Do, H.; Parang, K.; Tiwari, R.K.; Aliabadi, H.M. Tumor-targeted delivery of siRNA using fatty acyl-CGKRK peptide conjugates. Sci. Rep. 2017, 7, 6093. [CrossRef]

23. Jafarzade, B.S.; Bolhassani, A.; Sadat, S.M.; Yaghobi, R. Delivery of HIV-1 Nef protein in mammalian cells using cell penetrating peptides as a candidate therapeutic vaccine. Int. J. Pept. Res. Ther. 2017, 23, 145-153. [CrossRef]

24. Mandal, D.; Shirazi, A.N.; Parang, K. Cell-penetrating homochiral cyclic peptides as nuclear-targeting molecular transporters. Angew. Chem. Int. Ed. 2011, 50, 9633-9637. [CrossRef]

25. Shirazi, A.N.; Tiwari, R.K.; Oh, D.; Banerjee, A.; Yadav, A.; Parang, K. Efficient delivery of cell impermeable phosphopeptides by a cyclic peptide amphiphile containing tryptophan and arginine. Mol. Pharm. 2013, 10, 2008-2020. [CrossRef]

26. Shirazi, A.N.; Tiwari, R.; Chhikara, B.S.; Mandal, D.; Parang, K. Design and biological evaluation of cell-penetrating peptide-doxorubicin conjugates as prodrugs. Mol. Pharm. 2013, 10, 488-499. [CrossRef]

27. Weaver, B.A. How Taxol/paclitaxel kills cancer cells. Mol. Biol. Cell 2014, 25, 2677-2681. [CrossRef]

28. Wang, F.; Porter, M.; Konstantopoulos, A.; Zhang, P.; Cui, H. Preclinical development of drug delivery systems for paclitaxel-based cancer chemotherapy. J. Control Release 2017, 267, 100-118. [CrossRef]

29. Wall, M.E.; Wani, M.C.; Cook, C.E.; Palmer, K.H.; McPhail, A.A.; Sim, G.A. Plant antitumor agents. I. The isolation and structure of camptothecin, a novel alkaloidal leukemia and tumor inhibitor from camptotheca acuminate 1,2. J. Am. Chem. Soc. 1966, 88, 3888-3890.

30. Sparreboom, A.; Van Asperen, J.; Mayer, U.; Schinkel, A.H.; Smit, J.W.; Meijer, D.K.; Borst, P.; Nooijen, W.J.; Beijnen, J.H.; Tellingen, O.V. Limited oral bioavailability and active epithelial excretion of paclitaxel (Taxol) caused by P-glycoprotein in the intestine. Proc. Natl. Acad. Sci. USA 1997, 94, 2031-2035. [CrossRef]

31. Svenson, S.; Wolfgang, M.; Hwang, J.; Ryan, J.; Eliasof, S. Preclinical to clinical development of the novel camptothecin nanopharmaceutical CRLX101. J. Control. Release 2011, 153, 49-55. [CrossRef]

32. Li, N.; Cai, H.; Jiang, L.; Hu, J.; Bains, A.; Hu, J.; Gong, Q.; Luo, K.; Gu, Z. Enzyme-sensitive and amphiphilic PEGylated dendrimer-paclitaxel prodrug-based nanoparticles for enhanced stability and anticancer efficacy. ACS Appl. Mater. Interfaces 2017, 9, 6865-6877. [CrossRef]

33. Fox, M.E.; Guillaudeu, S.; Fréchet, J.M.; Jerger, K.; Macaraeg, N.; Szoka, F.C. Synthesis and in vivo antitumor efficacy of PEGylated poly (l-lysine) dendrimer- camptothecin conjugates. Mol. Pharm. 2009, 6, 1562-1572. [CrossRef]

34. Martins, S.; Tho, I.; Reimold, I.; Fricker, G.; Souto, E.; Ferreira, D.; Brandl, M. Brain delivery of camptothecin by means of solid lipid nanoparticles: Formulation design, in vitro and in vivo studies. Int. J. Pharm. 2012, 439, 49-62. [CrossRef]

35. He, Z.; Wan, X.; Schulz, A.; Bludau, H.; Dobrovolskaia, M.A.; Stern, S.T.; Montgomery, S.A.; Yuan, H.; Li, Z.; Alakhova, D.; Sokolsky, M. A high capacity polymeric micelle of paclitaxel: Implication of high dose drug therapy to safety and in vivo anti-cancer activity. Biomaterials 2016, 101, 296-309. [CrossRef]

36. Du, X.; Khan, A.R.; Fu, M.; Yu, A.; Zhai, G. Current development in the formulations of non-injection administration of paclitaxel. Int. J. Pharm. 2018, 542, 242-252. [CrossRef]

37. Zugates, G.T.; Anderson, D.G.; Little, S.R.; Lawhorn, I.E.; Langer, R. Synthesis of poly ( $\beta$-amino ester)s with thiol-reactive side chains for DNA delivery. J. Am. Chem. Soc. 2006, 128, 12726-12734. [CrossRef]

38. Sundaram, S.; Durairaj, C.; Kadam, R.; Kompella, U.B. Luteinizing hormone-releasing hormone receptor-targeted deslorelin-docetaxel conjugate enhances efficacy of docetaxel in prostate cancer therapy. Mol. Cancer Ther. 2009, 8, 1655-1665. [CrossRef]

39. Henne, W.A.; Doorneweerd, D.D.; Hilgenbrink, A.R.; Kularatne, S.A.; Low, P.S. Synthesis and activity of a folate peptide camptothecin prodrug. Bioorg. Med. Chem. Lett. 2006, 16, 5350-5355. [CrossRef]

40. Zhang, Q.; He, J.; Zhang, M.; Ni, P. A polyphosphoester-conjugated camptothecin prodrug with disulfide linkage for potent reduction-triggered drug delivery. J. Mat. Chem. B 2015, 3, 4922-4932. [CrossRef]

41. Darwish, S.; Sadeghiani, N.; Fong, S.; Mozaffari, S.; Hamidi, P.; Withana, T.; Yang, S.; Tiwari, R.K.; Parang, K. Synthesis and antiproliferative activities of doxorubicin thiol conjugates and doxorubicin-SS-cyclic peptide. Eur. J. Med. Chem. 2019, 161, 594-606. [CrossRef] 
42. Risinger, A.L.; Dybdal-Hargreaves, N.F.; Mooberry, S.L. Breast Cancer Cell Lines Exhibit Differential Sensitivities to Microtubule-targeting Drugs Independent of Doubling Time. Anticancer Res. 2015, 35, 5845-5850.

43. Thomas, C.J.; Rahier, N.J.; Hecht, S.M. Camptothecin: Current perspectives. Bioorg. Med. Chem. 2004, 12, 1585-1604. [CrossRef]

Sample Availability: Samples of the compounds are available for short time from the authors.

(C) 2019 by the authors. Licensee MDPI, Basel, Switzerland. This article is an open access article distributed under the terms and conditions of the Creative Commons Attribution (CC BY) license (http://creativecommons.org/licenses/by/4.0/). 